\title{
Hubungan Persepsi Dengan Motivasi Siswa Sekolah Menengah Kejuruan Dalam Konseling Perorangan
}

\author{
${ }^{1}$ Diastuti, ${ }^{2}$ Itsar Bolo Rangka, ${ }^{3}$ Wahyu Eka Prasetyaningtyas, ${ }^{4}$ Dian Renata \\ ${ }^{1234}$ Program Studi Bimbingan dan Konseling, Universitas Indraprasta PGRI Jakarta \\ Correspondence email: itsarbolo.rangka@unindra.ac.id
}

\begin{abstract}
Abstrak: Penelitian ini secara umum bertujuan untuk mengetahui hubungan persepsi siswa dengan motivasi siswa mengikuti konseling perorangan. Pengumpulan data dilakukan terhadap 288 siswa di SMK Al Hidayah 1 Jakarta. Analisis data menggunakan uji koefisien korelasi Gamma dan Somers'D. Hasil penelitian ditemukan bahwa nilai koefisien Gamma dan Somers 'D mencapai 0.496 dengan $Z_{\text {hitung }}>Z_{\text {tabel }}$ atau $6.523>1.96$. Hal ini berarti ada hubungan yang signifikan dan searah (positif) antara persepsi siswa terhadap pelayanan konseling dan motivasi siswa mengikuti layanan konseling perorangan.
\end{abstract}

Kata kunci: Konseling perorangan, persepsi, motivasi, konseling

\begin{abstract}
This study aimed to perform relationship between students perceptions on counselling practice with motivational student's in to individual counselling process. Data collection was conducted against 288 students in Al Hidayah 1 Vocational School Jakarta. Data analysis used the correlation coefficient test Gamma and Somers'D. The research findings showed coefficient Gamma and Somers'D test reached 0496 with $Z_{\text {hitung }}$ $>\mathrm{Z}_{\text {table }}$ or $6,523>1.96$. It means there is a significant relationship and positive direction between the perceptions of students towards counselling and motivation of students followed individual counselling service.
\end{abstract}

Keywords: Individual counseling; perceptions; motivation; counseling.

\section{PENDAHULUAN}

Pelayanan Bimbingan dan Konseling (BK) di sekolah terdiri atas 10 (sepuluh) jenis layanan dan 6 (enam) kegiatan pendukung. Tiap layanan dalam BK memiliki tujuan dan manfaat dalam setiap kegiatannya, salah satunya yaitu layanan konseling perorangan yang merupakan jantung hati dari pelayanan BK secara menyeluruh (Prayitno, 2012; Prayitno \& Amti, 2009).

Layanan konseling perorangan diberikan kepada seluruh siswa, baik untuk siswa yang datang sendiri kepada guru BK (Suwandi et al., 2014) ataupun siswa yang ditunjuk oleh guru mata pelajaran atau wali kelas untuk diundang melakukan konseling perorangan dengan guru BK (Prayitno, 2012). Siswa dapat menerima layanan dari konselor di ruang BK atau pusat konseling di sekolah, baik pada jam pembelajaran maupun di luar jam pembelajaran. Idealnya siswa akan mencari pusat pelayanan konseling saat mereka membutuhkan konsultasi dan/atau mengalami masalah; dan rata-rata siswa mengunjungi pusat pelayanan konseling sebanyak 5 kali tiap minggu (VasquezMartinez, 2015). Akan tetapi, banyak siswa yang menghindari untuk berpartisipasi dalam sesi konseling (Ryan, Lynch, Vansteenkiste, \& Deci, 2010) karena beberapa alasan sebagaimana yang diidentifikasi oleh Snyder, Hill, \& Derksen, (1972), yaitu: (1) klien tidak mengenal dengan baik "apa itu konseling", (2) adanya "stigma" yang memandang konseling sebagai hal yang tidak begitu menarik untuk diikuti bahkan sebaiknya dihindari, (3) klien tidak memiliki 
informasi yang menyeluruh terkait proses konseling, (4) teman dekat diletakkan pada pilihan pertama bagi klien ketika menghadapi masalah pribadi dibanding orang lainnya, termasuk konselor, (5) faktor gangguan psikologis yang amat berat, (6) pengaruh orang lain untuk tidak menggunakan layanan konseling.

Siswa di jenjang pendidikan menengah, khususnya di Sekolah menengah kejuruan (SMK) merupakan kelompok individu yang perlu mendapatkan perhatian khusus. Hal ini didasari fakta bahwa periode perkembangan usia remaja terjadi banyak perubahan yang cukup singnifikan yang di satu sisi dapat menguntungkan dan di sisi lain merugikan siswa apabila tidak ditangani dengan baik (Hurlock, 2001).

Perubahan-perubahan tersebut di atas meliputi fisik, emosional, hubungan sosial dengan orang lain, adaptasi lingkungan, suasana belajar, dan berbagai masalah yang mengikutinya (Santrock, 1997). Dalam hal ini, keberadaan pelayanan BK dibutuhkan untuk memfasilitasi perkembangan siswa selaku peserta didik di sekolah (Prayitno, 2012). Akan tetapi, keberadaan pelayanan BK di sekolah tidaklah dirasa cukup apabila pelayanan BK itu sendiri tidak dapat memberikan manfaat yang sebesarbesarnya bagi siswa, sehingga siswa tidak memiliki motivasi untuk menggunakan akses pelayanan BK di sekolah.

Penelitian yang dilakukan oleh Strowig \& Sheets, (1967) dalam kaitannya dengan sikap siswa terhadap pelayanan BK ditemukan bahwa siswa pada tahun pertama menujukkan sikap negatif terhadap layanan BK di sekolah, dan mulai cenderung positif pada tahun kedua. Selanjutnya, penelitian yang dilakukan oleh Wantz \& Firmin, (2011) ditemukan bahwa siswa lebih peduli terhadap proses konseling, apabila konselor memiliki kepedulian dalam memberikan pelayanan yang berkualitas, memiliki wawasan yang luas (Rubin, 2014), dan memiliki self-efikasi diri yang baik (Iarussi, Tyler, Littlebear, \& Hinkle, 2013). Mencermati hal tersebut, maka peran konselor sebagai orang dewasa dalam menjalin hubungan dan memberikan perhatian terhadap siswa (Michael John Scheel, Madabhushi, \& Backhaus, 2009) mutlak diperlukan.

Disadari pula bahwa keberhasilan proses konseling lainnya terletak pada keberfungsian dan kolaborasi konselor dengan klien (Michael J
Scheel, Davis, \& Henderson, 2012). Banyak konselor sangat mengharapkan klien mereka menampilkan motivasi untuk mengikuti konseling, meskipun kenyataannya diketahui sebenarnya motivasi klien mengikuti konseling cukup rendah (Ryan et al., 2010). Pada kondisi tersebut, konselor harus mampu meletakkan pandangan bahwa satu-satunya orang yang mampu memecahkan masalah, adalah orang (klien) itu sendiri, dan konselor wajib menjamin dan memfasilitasi terciptanya suasana konseling yang penuh kepedulian dan rasa empati (Lindsay \& Langevin, 2017; Prayitno, 2012). Konselor juga harus dapat memupuk terciptakan "aliansi teraputik" yang maksimal dalam proses konseling (Rangka, 2015) dengan tanpa membeda-bedakan nilai-nilai, budaya, kepercayaan, cara pandang terhadap kehidupan, kebutuhan dan ekspektasi diri klien (Lin, 2001). Hal ini dapat membuat siswa memandang kehadiran pelayanan BK di sekolah sebagai suatu keuntungan.

Diperlukan pula kesadaran dalam diri siswa selaku klien untuk melihat konseling sebagai suatu hubungan perbantuan yang menjanjikan terentaskannya masalah yang dihadapi oleh siswa. Akan tetapi, hal tersebut hanya dapat tercipta jika ada persepsi yang baik terhadap layanan konseling dan motivasi untuk mengikuti konseling.

Persepsi merujuk pada bagaimana otak manusia memproses dan mengorganisasikan seluruh arus informasi yang berasal dari luar ke dalam diri manusia berdasarkan daya tangkap / kemampuan panca indra tertentu (Thomason, 2008). Sementara itu, pengertian motivasi dapat diartikan sebagai mekanisme internal dan eksternal (Kleinginna \& Kleinginna, 1981), yang mendorong manusia untuk melakukan suatu hal tertentu (Morgan, Harmon, \& Maslin-Cole, 1990). Persepsi klien terhadap konseling sangat penting untuk membantu konselor merancang program yang tepat bagi pelayanan konseling yang akan dilakukannya (Paulson, Truscott, \& Stuart, 1999). Hal yang sama pula berlaku bagi aspek motivasi klien dalam mengikuti konseling karena motivasi klien adalah kunci utama daripada kekuatan dan keberhasilan konseling (Ryan et al., 2010; Michael J Scheel et al., 2012).

Faktor-faktor yang mempengaruhi persepsi dan motivasi siswa melakukan konseling telah banyak didokumentasikan oleh para ahli, antara lain ekpresi yang ditampilkan konselor dalam proses konseling (Paulson et al., 
1999), ketepatan waktu dalam konseling (Legg \& Newton, 2016), pengalaman yang didapatkan selama proses konseling berlangsung (Good, Komiya, Good, \& Sherrod, 1999; Houfek, SoltisVaughan, Atwood, Reiser, \& Schaefer, 2015) kelancaran dalam berkomunikasi (Gatti, Brivio, \& Calciano, 2016; Good et al., 1999) adanya kolaborasi yang sehat antara konselor dengan klien dengan prinsip pemberdayaan (Gruhl \& Van Leuven, 2014), adanya upaya untuk menegakkan kemandirian klien dengan memberikan kebebasan untuk memilih solusi (Nirenberg, Baird, Longabaugh, \& Mello, 2013), keterbukaan secara emosional (Good et al., 1999), dan ketersediaan fasilitas pendukung untuk melaksanakan konseling (Snyder et al., 1972).

Tujuan penelitian ini, yaitu: (1) untuk mengetahui persepsi siswa mengenai layanan konseling perseorangan yang diberikan guru BK, (2) untuk mengetahui motivasi siswa mengikuti konseling perorangan, dan (3) untuk mengetahui hubungan persepsi siswa dengan motivasi siswa mengikuti konseling perorangan di SMK Al Hidayah I Jakarta. Hipotesis yang diajukan dalam penelitian ini, yaitu ada hubungan uang singnifikan antara persepsi siswa terhadap pelayanan konseling dan motivasi siswa mengikuti layanan konseling perorangan.

Dengan demikian guru BK dapat melakukan peningkatan rencana pengembangan pelayanan konseling perorangan di sekolah serta dapat lebih meningkatkan kegiatan-kegiatan yang dapat meningkatan motivasi siswa mengikuti layanan konseling perorangan.

\section{METODE}

Penelitian ini menggunakan metode penelitian kuantitatif (survei) korelasional. Tempat penelitian, yaitu di SMK Al Hidayah 1
Jakarta. Populasi penelitian ini adalah seluruh siswa-siswi SMK Al Hidayah 1 Jakarta Tahun Ajaran 2015/2016 yang berjumlah 1.024 siswa. Dari populasi tersebut ditarik sampel secara acak dan proporsional menggunakan rumus Slovin Formula (Sevilla, 1992), sehingga didapatkan besaran sampel, yaitu 288 siswa.

Pengumpulan data dilakukan dengan menggunakan angket dengan Rating Scale, dimana skala pengukuran pada data penelitian ini merupakan skala ordinal, untuk membedakan kategori berdasarkan tingkat atau urutan. Sebagai unit ukur, persepsi siswa terhadap layanan konseling perorangan sebagai variabel $X$ meliputi aspek persepsi siswa atas (1) tujuan dan manfaat konseling perorangan, (2) peran konselor dan konseli dalam konseling perorangan, dan (3) proses dan kegiatan dalam konseling perorangan.

Sementara itu, motivasi siswa mengikuti konseling perorangan sebagai variabel $\mathrm{Y}$ meliputi aspek (1) ketertarikan terhadap suasana konseling, (2) dorongan untuk melakukan konseling, dan (3) kebutuhan untuk melakukan konseling. Reliabilitas skor angket pada 32 butir item skala persepsi siswa terhadap layanan konseling perorangan mencapai $0.89 ;$ dan reliabilitas skor angket pada 32 butir item skala motivasi siswa mengikuti konseling perorangan mencapai 0.90 . Analisis data dalam penelitian ini menggunakan uji non-parametrik yaitu koefisien korelasi Gamma dan Somers 'D.

\section{HASIL DAN PEMBAHASAN}

\section{Persepsi Siswa terhadap Layanan Konseling Perorangan}

Gambaran terkait persepsi siswa terhadap layanan konseling perorangan sebagaimana disajikan dalam Tabel 1 berikut.

Tabel 1. Deskripsi persepsi siswa terhadap layanan konseling perorangan di SMK

\begin{tabular}{cccc}
\hline Skor & Kategori & Frekuensi & Prosentase \\
\hline$>\mathbf{1 0 4}$ & Sangat Baik & 62 & $22 \%$ \\
\hline $\mathbf{8 9 - 1 0 4}$ & Baik & 184 & $64 \%$ \\
\hline $\mathbf{7 3 - 8 8}$ & Cukup Baik & 37 & $13 \%$ \\
\hline $\mathbf{5 7 - 7 2}$ & Kurang Baik & 5 & $2 \%$ \\
\hline$>\mathbf{5 6}$ & Tidak baik & 0 & $0 \%$ \\
\hline & Jumlah & 288 & $100 \%$
\end{tabular}

Sumber: Diolah dari data penelitian 2016

Dari Tabel 1 di atas, dapat dilihat sebesar $22 \%$ siswa yang memiliki persepsi terhadap layanan konseling perorangan dalam kategori sangat baik sebanyak 62 siswa, sebesar $64 \%$ 
kategori baik sebanyak 184 siswa, sebanyak 37 siswa dengan presentase 13\% kategori cukup baik, sedangkan untuk kategori kurang baik sebanyak 5 siswa dengan presentase sebesar $2 \%$, dan $0 \%$ atau tidak ada siswa dalam kategori tidak baik. Dengan demikian, mayoritas siswa SMK Al Hidayah 1 Jakarta memiliki tingkat persepsi yang baik terhadap layanan konseling perorangan.

Akan tetapi, jika ditelaah berdasarkan program keahlian tertentu di SMK Al Hidayah 1 Jakarta, yaitu (1) Program keahlian akuntansi, (2) Program Keahlian Administrasi Perkantoran, (3) Program Keahlian Pemasaran, dan (4) Program Keahlian Teknik Komputer dan Jaringan, ditemukan variasi persepsi yang berbeda-beda.

Persepsi siswa terhadap layanan konseling perorangan pada program keahlian Akuntansi ditemukan bahwa 50 (69\%) siswa mempersepsikan Baik, $16 \quad(22 \%)$ siswa mempersepsikan sangat baik, $6(8 \%)$ siswa mempersepsikan cukup baik dan tidak ada siswa mempersepsikan layanan konseling perorangan kurang baik atau tidak baik. Sementara itu, pada program keahlian Administrasi Perkantoran ditemukan bahwa $52 \quad(63 \%)$ siswa mempersepsikan Baik, 13 (16\%) siswa

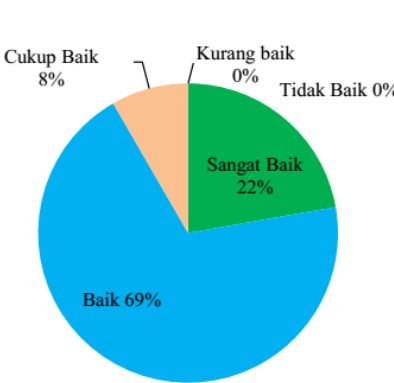

(a) Akuntansi

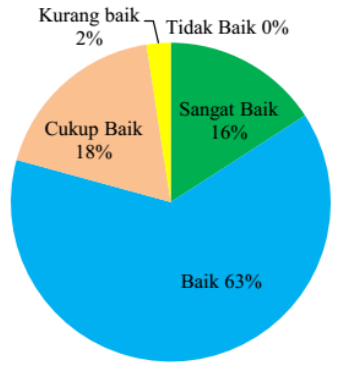

(b) Admınıstrası Perkantoran mempersepsikan sangat baik, $15(18 \%)$ siswa mempersepsikan cukup baik dan 2 (2\%) siswa mempersepsikan kurang baik, dan tidak ada siswa mempersepsikan layanan konseling perorangan kurang baik atau tidak baik.

Lebih lanjut, pada program keahlian Pemasaran ditemukan bahwa $33(63 \%)$ siswa mempersepsikan Baik, $10 \quad(19 \%)$ siswa mempersepsikan sangat baik, 7 (13\%) siswa mempersepsikan cukup baik dan 2 (4\%) siswa mempersepsikan kurang baik, dan tidak ada siswa mempersepsikan layanan konseling perorangan kurang baik atau tidak baik.

Sementara itu, pada program keahlian Teknik Komputer dan Jaringan, ditemukan bahwa $49(60 \%)$ siswa mempersepsikan Baik, 23 (28\%) siswa mempersepsikan sangat baik, 9 (11\%) siswa mempersepsikan cukup baik dan 1 (1\%) siswa mempersepsikan kurang baik, dan tidak ada siswa mempersepsikan layanan konseling perorangan kurang baik atau tidak baik.

Perbandingan gambaran persepsi siswa terhadap layanan konseling perorangan berdasarkan program keahlian sebagaimana dijabarkan di atas dapat dilihat pada Gambar 1 berikut.
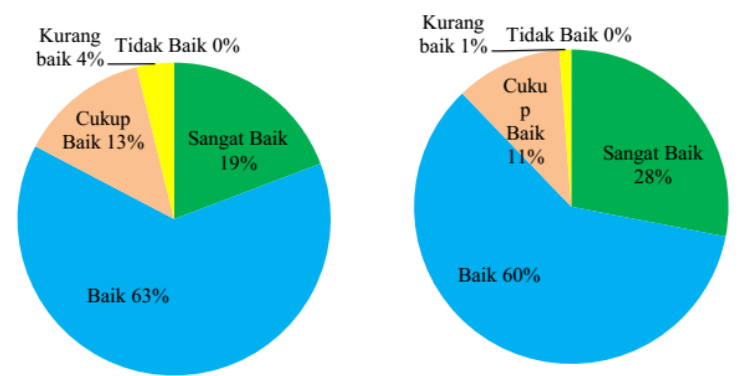

(c) Pemasaran

(d) Tek. Komputer dan Jaringan

Gambar 1. Perbandingan deskripsi persepsi siswa terhadap layanan konseling perorangan berdasarkan program keahlian SMK Al Hidayah 1 Jakarta

\section{Motivasi siswa mengikuti konseling perorangan}

Analisis deskriptif juga dilakukan untuk melihat bagaimana motivasi siswa mengikuti konseling perorangan. Gambaran terkait motivasi siswa untuk mengikuti konseling perorangan secara keseluruhan di SMK Al Hidayah 1 Jakarta sebagaimana disajikan dalam Tabel 2 berikut.

Tabel 2. Deskripsi motivasi siswa mengikuti konseling perorangan di SMK

\begin{tabular}{cccc}
\hline Skor & Kategori & Frekuensi & Prosentase \\
\hline$>\mathbf{1 0 7}$ & Sangat Tinggi & 82 & $28 \%$ \\
\hline $\mathbf{9 2 - 1 0 7}$ & Tinggi & 152 & $53 \%$ \\
\hline $\mathbf{7 5 - 9 1}$ & Cukup Tinggi & 49 & $17 \%$ \\
\hline
\end{tabular}




\begin{tabular}{cccc}
\hline Skor & Kategori & Frekuensi & Prosentase \\
\hline $\mathbf{5 9 - 7 4}$ & Rendah & 5 & $2 \%$ \\
\hline$>\mathbf{5 8}$ & Sangat Rendah & 0 & $0 \%$ \\
\hline & Jumlah & 288 & $100 \%$ \\
\hline
\end{tabular}

Sumber: Diolah dari data penelitian 2016

Berdasarkan Tabel 2 di atas, tidak ditemukan siswa yang tidak memiliki motivasi untuk mengikuti konseling perorangan. Semua siswa memiliki motivasi untuk melakukan konseling dengan variasi, yaitu sebanyak 82 (28\%) siswa memiliki motivasi yang sangat tinggi untuk mengikuti konseling perorangan; sebanyak $152(53 \%)$ siswa memiliki motivasi yang tinggi untuk mengikuti konseling perorangan; sebanyak 49 (17\%) memiliki motivasi yang cukup tinggi untuk mengikuti konseling perorangan dan hanya $5(2 \%)$ siswa yang memiliki motivasi yang rendah untuk melakukan konseling perorangan.

Dengan demikian, mayoritas siswa SMK Al Hidayah 1 Jakarta memiliki tingkat motivasi yang tinggi untuk mendapatkan akses pelayanan konseling perorangan di sekolahnya.

Sebagaimana analisis deskriptif pada variabel persepsi siswa terhadap layanan konseling perorangan, maka penulis juga melakukan analisis untuk membandingkan capaian motivasi siswa untuk mengikuti konseling perorangan berdasarkan program keahlian di SMK Al Hidayah 1 Jakarta.

Pada program keahlian akuntansi ditemukan bahwa $44(61 \%)$ siswa memiliki motivasi yang tinggi, 18 (25\%) siswa memiliki motivasi yang sangat tinggi, $10(14 \%)$ siswa memiliki motivasi yang tinggi dan tidak ada siswa yang memiliki motivasi untuk mengikuti konseling perorangan rendah atau sangat rendah. Sementara itu, pada program keahlian
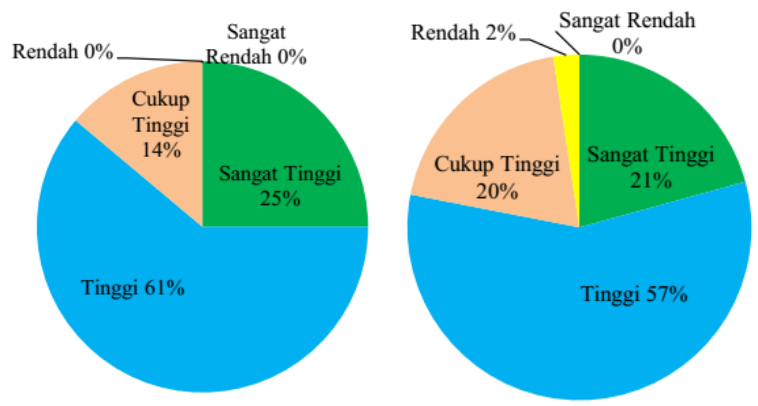

$\begin{array}{ll}\text { a) Akuntansi } & \text { (b) Administrasi Perkantoran }\end{array}$
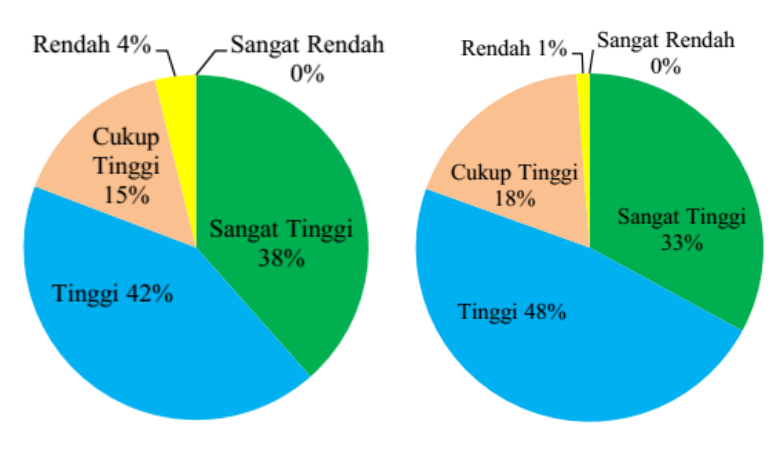

Administrasi Perkantoran ditemukan bahwa 47 (57\%) siswa memiliki motivasi yang tinggi untuk mengikuti konseling perorangan, 17 (21\%) siswa memiliki motivasi yang sangat tinggi, 16 (20\%) siswa memiliki motivasi yang cukup tinggi, 2 (2\%) siswa memiliki motivasi yang rendah, dan tidak ada siswa yang memiliki motivasi sangat rendah untuk mengikuti konseling perorangan.

Lebih lanjut, pada program keahlian Pemasaran ditemukan bahwa $22(42 \%)$ siswa memiliki motivasi yang tinggi untuk mengikuti konseling perorangan, 20 (38\%) siswa memiliki motivasi yang sangat tinggi, $8(15 \%)$ siswa memiliki motivasi yang cukup tinggi, 2 (4\%) siswa memiliki motivasi yang rendah, dan tidak ada siswa memiliki motivasi yang sangat rendah untuk mengikuti konseling perorangan.

Sementara itu, pada program keahlian Teknik Komputer dan Jaringan, ditemukan bahwa 39 (48\%) siswa memiliki motivasi yang tinggi untuk mengikuti konseling perorangan, 27 $(33 \%)$ siswa memiliki motivasi yang sangat tinggi, 15 (18\%) siswa memiliki motivasi yang cukup tinggi, 1 (1\%) siswa siswa memiliki motivasi yang rendah, dan tidak ada siswa memiliki motivasi yang sangat rendah untuk mengikuti konseling perorangan.

Perbandingan gambaran motivasi siswa untuk mengikuti konseling perorangan berdasarkan program keahlian sebagaimana dijabarkan di atas dapat dilihat pada Gambar 2 berikut.

(c) Pemasaran

(d) Tek. Komputer dan Jaringan

Gambar 2. Perbandingan deskripsi motivasi siswa untuk mengikuti konseling perorangan berdasarkan program keahlian di SMK Al Hidayah 1 Jakarta 


\section{Analisis Data Penelitian}

Analisis data dilakukan dengan menggunakan korelasi dengan data kuantitatif. Sebelumnya, dilakukan uji persyaratan analisis data yang meliputi (1) uji normalitas untuk mengetahui apakah data berasal dari populasi berdistribusi normal atau tidak, dan (2) uji linearitas untuk mengetahui hubungan antara variabel bebas dan variabel terikat linier atau tidak.

Berdasarkan uji normalitas data ditemukan bahwa bahwa nilai probabilitas (Asymp. Sig. (2-tailed)) data pada skala persepsi dan motivasi siswa mengikuti konseling perorangan sebesar 0.04 dengan menggunakan taraf signifikansi alpha 5\% atau (0.05), maka diketahui bahwa nilai probabilitas 0.04 lebih kecil dari 0.05, maka H0 ditolak. Sehingga dapat disimpulkan bahwa data persepsi dan motivasi siswa mengikut konseling perorangan berdistribusi tidak normal.

Selanjutnya, pada uji linearitas ditemukan bahwa data pada variabel penelitian memiliki nilai signifikansi yang lebih kecil dari 0.05 , yaitu $0.000<0.05$, hal ini menunjukkan bahwa variabel penelitian adalah linear. Hal ini juga dapat dilihat pada Gambar 3 berikut.

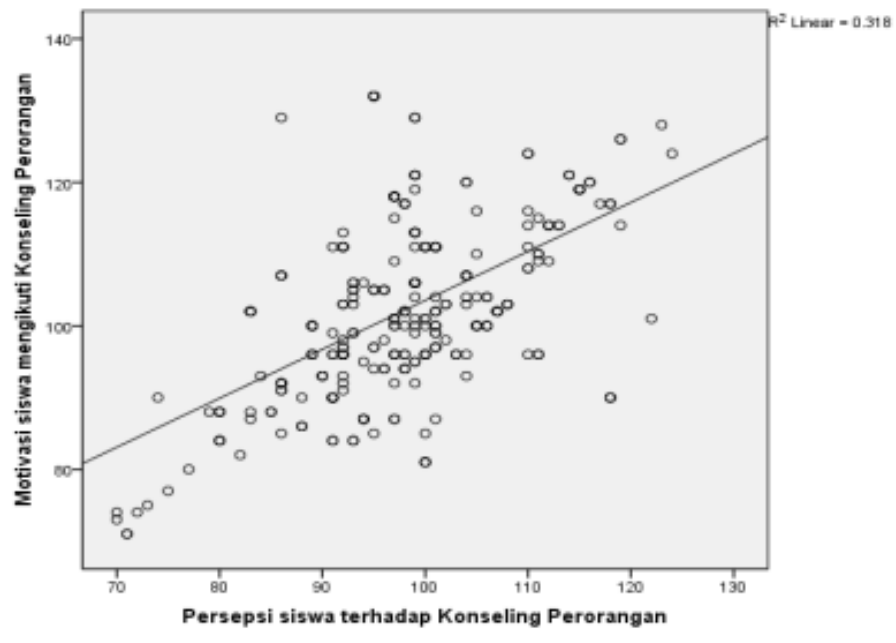

Gambar 3. Scatterplot hubungan antara variabel X dan Y

Berdasarkan gambar Scatterplot di atas diketahui hubungan antar variabel dalam bentuk titik-titik pertemuan nilai kuantitatif antara antara variabel $\mathrm{X}$ dan $\mathrm{Y}$ yang hendak dianalisis mengikuti garis lurus. Jadi peningkatan atau penurunan kuantitas di satu variabel akan diikuti secara linear oleh peningkatan atau penurunan kuantitas di variabel lainnya. Dengan data skala pengukuran pada data penelitian ini merupakan skala ordinal pada sebaran populasi yang berdistribusi tidak normal dan variabel penelitian bersifat linear maka disimpulkan bahwa untuk melakukan pengujian hipotesis dalam penelitian ini menggunakan statistik non-parametrik menggunakan uji korelasi Gamma dan Somer's $D$. Pengujian hipotesis dengan penggunaan rumus Gamma dan Somer's D.

Adapun hasil uji hipotesis diperoleh nilai koefisien korelasi antara persepsi siswa terhadap layanan konseling perorangan dengan motivasi siswa mengikuti konseling perorangan sebesar
$0.496 \neq 0$, menunjukkan bahwa terdapat hubungan. Dikatakan ada hubungan jika nilai Sommer's $D$ berkisar antara -1 (hubungan tidak searah sempurna) dan +1 (hubungan searah sempurna). Nilai 0.496 mendekati nilai 0.5 dengan kategori korelasi yang cukup kuat dengan hubungan yang searah (positif) antara persepsi dengan motivasi siswa mengikuti konseling perorangan di SMK Al Hidayah 1 Jakarta.

Untuk mengetahui apakah koefisien korelasi tersebut memiliki hubungan yang bermakna atau tidak, dilakukan uji signifikansi antara variabel $\mathrm{X}$ dan variabel $\mathrm{Y}$ dengan taraf signifikansi $(\alpha) 5 \%$ atau sama dengan 0.05 . Apabila $-Z$ Score $\geq-Z$ tabel atau $+Z$ Score $\geq+Z$ tabel, maka dikatakan ada hubungan yang signifikan. Sebaliknya, Apabila $-Z$ Score $\leq-Z$ tabel atau $+Z$ Score $\leq+Z$ tabel, maka dikatakan tidak ada hubungan yang signifikan. Estimasi nilai Z score pada uji Somer's dilakukan melalui perhitungan sebagai berikut: 


$$
\begin{aligned}
& z=\frac{0.496}{\frac{4}{4(4)} \sqrt{\frac{\left(4^{2}-1\right)(4+1)}{288(4-1)}}} \\
& z=\frac{0.496}{0.250 \cdot \sqrt{\frac{80}{864}}}=\frac{0.496}{0.250 .0 .304}=\frac{0.496}{0.076}=6.523
\end{aligned}
$$

Untuk mengetahui $\mathrm{Z}_{\text {tabel }}$ sebagai berikut :

$$
Z_{\text {tabel }}=\frac{\propto}{2}=\frac{0.05}{2}=1.96
$$

Berdasarkan analisis data yang telah dilakukan dapat diketahui bahwa nilai $\mathrm{Z}_{\text {hitung }}>$ $z_{\text {tabel }}$ atau $6.523>1.96$, sehingga dapat diputuskan untuk menolak $\mathrm{H} 0$ atau ada hubungan yang signifikan antara persepsi siswa terhadap pelayanan konseling dan motivasi siswa mengikuti layanan konseling perorangan.

\section{SIMPULAN DAN SARAN}

Berdasarkan hasil analisis data dan pembahasan yang dilakukan atas Hubungan Persepsi dengan Motivasi Siswa Mengikuti Konseling Perorangan di Sekolah Menengah Kejuruan (SMK) Al Hidayah 1 Jakarta, dapat disimpulkan hal-hal sebagai berikut: (1) Persepsi siswa terhadap layanan konseling perorangan di SMK Al Hidayah 1 Jakarta berada pada kategori Baik, (2) Motivasi siswa mengikuti konseling perorangan di SMK Al Hidayah 1 Jakarta berada pada kategori Tinggi, dan (3) terdapat hubungan yang cukup kuat, positif (searah) dan signifikan antara persepsi dengan motivasi siswa mengikuti konseling perorangan di SMK Al Hidayah 1 Jakarta.

Guru Bimbingan dan Konseling di sekolah hendaknya mampu menciptakan suasana kondusif dan membangun persepsi siswa ke arah yang positif terhadap layanan konseling perorangan serta meningkatkan kemampuan dan kualitas sebagai guru bimbingan dan konseling di sekolah. Dengan membekali keterampilan dan wawasan yang luas, seorang guru bimbingan dan konseling disekolah dapat memberikan pelayanan konseling khususnya layanan konseling perorangan dengan lebih baik dan semakin meningkat kualitas dalam proses pelaksanaannya dan motivasi siswa untuk mengikuti konseling perorangan juga menjadi lebih tinggi.

Para siswa hendaknya dapat secara sukarela dan memberikan respon positif terhadap layanan konseling perorangan sehingga siswa dapat memanfaatkan layanan konseling perorangan dengan sebaik-baiknya untuk membantu hambatan-hambatan yang dialami serta dalam rangka mengenali dan mengembangkan potensi yang dimiliki. Sehingga dengan anggapan atau persepsi yang semakin baik atas layanan konseling perorangan, maka tingkat motivasi yang dimiliki akan semakin tinggi untuk berperan dalam layanan tersebut.

\section{DAFTAR RUJUKAN}

Gatti, F. M., Brivio, E., \& Calciano, S. (2016). "Hello! I know you help people here, right?": A qualitative study of young people's acted motivations in text-based counseling. Children and Youth Services Review, 71, 27-35. https://doi.org/10.1016/j.childyouth.2016.1 0.029

Good, G. E., Komiya, N., Good, G. E., \& Sherrod, N. B. (1999). Emotional Openness as a Predictor of College Students $\hat{a} €^{\mathrm{TM}}$ Attitudes Toward Seeking Professional Psychological Help Emotional Openness as a Predictor of College Students $\hat{a} €^{\mathrm{TM}}$ Attitudes Toward Seeking Psychological Help. Journal of Counseling Psychology, 47(June 2016), 138-143. https://doi.org/10.1037/AJ022-0167

Gruhl, E., \& Van Leuven, K. A. (2014). Motivational interviewing for adolescents: Behavior counseling for diet and exercise. 
Journal for Nurse Practitioners, 10(7), 493-499.

https://doi.org/10.1016/j.nurpra.2014.04.00 6

Houfek, J. F., Soltis-Vaughan, B. S., Atwood, J. R., Reiser, G. M., \& Schaefer, G. B. (2015). Adults' perceptions of genetic counseling and genetic testing. Applied Nursing Research, 28(1), 25-30. https://doi.org/10.1016/j.apnr.2014.03.001

Hurlock, E. B. (2001). Developmental psychology. Tata McGraw-Hill Education.

Iarussi, M. H., Tyler, J. M., Littlebear, S., \& Hinkle, M. S. (2013). Integrating Motivational Interviewing into a Basic Counseling Skills Course to Enhance Counseling Self-Efficacy. The Professional Counselor, 3(3), 161-175. https://doi.org/10.15241/mhi.3.3.161

Kleinginna, P. R., \& Kleinginna, A. M. (1981). A categorized list of motivation definitions, with a suggestion for a consensual definition. Motivation and Emotion, 5(3), 263-291.

https://doi.org/10.1007/BF00993889

Legg, K. T., \& Newton, M. (2016). Counselling adults who experience a first seizure. Seizure, https://doi.org/10.1016/j.seizure.2016.09.01 2

Lin, Y. (2001). The effects of counseling styles and stages on perceived counselor effectiveness from Taiwanese female university clients. Special Issue: Research in Counseling Process and Outcome, 8(1), 35-60. Retrieved from http://ovidsp.ovid.com/ovidweb.cgi?T=JS\& $\mathrm{PAGE}=$ reference $\& \mathrm{D}=\mathrm{psyc} 3 \& \mathrm{NEWS}=\mathrm{N} \&$ $\mathrm{AN}=2002-01509-003$

Lindsay, A., \& Langevin, M. (2017). Psychological counseling as an adjunct to stuttering treatment: Clients' experiences and perceptions. Journal of Fluency Disorders, 52, 1-12. https://doi.org/10.1016/j.jfludis.2017.01.00 3

Morgan, G. A., Harmon, R. J., \& Maslin-Cole, C. A. (1990). Mastery motivation: Definition and measurement. Early Education \& Development, 1(5), 318-339. https://doi.org/10.1207/s15566935eed0105

Nirenberg, T., Baird, J., Longabaugh, R., \& Mello, M. J. (2013). Motivational counseling reduces future police charges in court referred youth. Accident Analysis and Prevention, 53, 89-99. https://doi.org/10.1016/j.aap.2013.01.006

Paulson, B., Truscott, D., \& Stuart, J. (1999). (Paulson, Truscott \& Stuart, 1999).pdf. Journal of Counseling \& Development. https://doi.org/10.1037/0022-0167.46.3.317

Prayitno. (2012). Jenis Layanan dan Kegiatan Pendukung Konseling. Padang: Jurusan Bimbingan dan Konseling FIP-UNP.

Prayitno, \& Amti, E. (2009). Dasar-Dasar Bimbingan dan Konseling. Jakarta: Rhineka Cipta.

Rangka, I. B. (2015). Genogram and Narrative Counseling: a Approach for Helping Student to Find Direction of Career Choice. In The Association of Psychological and Educational Counselors of Asia-Pacific (APECA): A Counseling Based Approach to Health and Wellness. Salatiga: UKSW Salatiga.

Rubin, O. (2014). Perceptions of Educational Counseling as a Profession: The Role of Education. Procedia - Social and Behavioral Sciences, 116, 3646-3648. https://doi.org/10.1016/j.sbspro.2014.01.81 7

Ryan, R. M., Lynch, M. F., Vansteenkiste, M., \& Deci, E. L. (2010). Motivation and Autonomy in Counseling, Psychotherapy, and Behavior Change: A Look at Theory and Practice 17 . The Counseling Psychologist, 39(2), 193-260. https://doi.org/10.1177/0011000009359313

Santrock, J. W. (1997). Life-span development. New York: Brown \& Benchmark Publishers Dubuque, IA.

Scheel, M. J., Davis, C. K., \& Henderson, J. D. (2012). Therapist Use of Client Strengths: A Qualitative Study of Positive Processes. The Counseling Psychologist, 20(5), 1-36. https://doi.org/10.1177/0011000012439427

Scheel, M. J., Madabhushi, S., \& Backhaus, A. (2009). The Academic Motivation of AtRisk Students in a Counseling Prevention Program. Counseling Psychologist, 37(8), 1147-1178. https://doi.org/10.1177/0011000009338495

Sevilla, C. G. (1992). Research methods. Quezon City: Rex Bookstore, Inc.

Snyder, J. F., Hill, C. E., \& Derksen, T. P. (1972). Why some students do not use university counseling facilities. Journal of Counseling Psychology, 19(4), 263-268. 
https://doi.org/10.1037/h0033075

Strowig, R. W., \& Sheets, S. E. (1967). Student Perception of Counselor Role. Personnel and Guidance Journal, May, 926-931.

Suwandi, A., Folastri, S., Rangka, I. B., Sofyan, A., Hidayat, R., \& Fijriani. (2014). Teknik dan Praktik Laboratorium Konseling: Panduan Praktis-Operasional Konseling Perorangan (I). Bandung: Mujahid Press.

Thomason, T. (2008). The Influence of Perception on the Search for Meaning in Counseling. Wisconsin Counseling Journal, (22), 39-47. Retrieved from http://works.bepress.com/timothy_thomaso $\mathrm{n} / 17 /$

Vasquez-Martinez, C. (2015). Student Perception. Statewide Agricultural Land Use Baseline 2015, 1. https://doi.org/10.1017/CBO978110741532 4.004

Wantz, R. A., \& Firmin, M. (2011). Perceptions of professional counselors: Survey of college student views. The Professional Counselor: Research and Practice, 1(1), 71-81. https://doi.org/10.15241/raw.1.1.71 